\title{
THE STATUS OF MANATEES IN THE GUIANAS
}

\author{
By G. C. L. Bertram and C. K. Ricardo Bertram \\ Cambridge
}

Manatees appear on the list of animals deemed by the Survival Commission of the International Union for Conservation of Nature to be in danger of extermination. Fortunately they are not yet very high on the danger list, but are nevertheless in need of proper conservation. A study of these animals in British Guiana and neighbouring countries was therefore undertaken early in 1962 to investigate the problems involved in their use and protection. ${ }^{1}$ British Guiana was chosen for this study since it was believed still to have as large a stock of manatees as any country, and because helpful people there made possible the best use of the three months available. This paper is concerned primarily with the status of manatees, both as regards their present abundance and their possible economic uses. Other aspects of the work will be published elsewhere. ${ }^{2}$

The American manatee can still be found in small numbers in many places round the Gulf of Mexico and the Caribbean sea. ${ }^{3}$ The sub-species on the coasts of central and northern South America is Trichechus manatus manatus, while another subspecies T. m. latirostris lives round the Florida Peninsula. There is also a smaller species, $T$. inunguis, landlocked in the Amazon basin, which may occasionally penetrate into southern British Guiana close to the boundary with Brazil. Across the Atlantic, another species, T. senegalensis, occurs in coastal waters of West Africa and often penetrates far up some of the rivers. Its present status is doubtful.

In British Guiana the manatees live mainly in the rivers of the coastal plain, particularly in the regions of wet savannah where suitable vegetation is available for food. They are also found in the sea but there the water is so turbid and there is so little rooted vegetation that it is more likely that the manatees are travelling from one river to another than that they are living a really marine life. They are to be found in greatest numbers in the extreme north-west of British Guiana and in the eastern region on both sides of the border with Surinam (formerly Dutch Guiana), but nowhere are they abundant. Everywhere they are said to be less frequently seen than in former times. This suggests greater scarcity, but the increasing use of powered boats, including dug-out canoes with outboard motors, may be scaring the animals away from some reaches of the rivers and so restricting their distribution. Any estimate of actual numbers, however, is bound to be extremely tentative, because the only information available consists of answers to innumerable questionings of as many

1 The work was made possible first of all by a grant from the Zoological Society of New York, followed by other generous grants from the Nuffield Foundation, the Zoological Society of London and Cambridge University (Foreign Travel Fund).

2 "In Search of Mermaids: The Manatees of the Guianas", by Colin Bertram. Peter Davies, 1963, and a paper for Zoologica in preparation.

3 Together with the Dugongs and the recently extinct Steller's Sea-Cow, they are included in G. M. Allen's Extinct and Vanishing Mammals of the Western Hemisphere with the Marine Species of all the Oceans, published in 1942. 
people from as many areas as possible. However, the conclusion is that there are probably some thousands, but not tens of thousands, of manatees at present in British Guiana. There are fewer in Surinam and virtually none in Cayenne where the coastal plain disappears and the mountains come down to the sea. Information from Venezuela and countries to the west is insufficient to give any idea of the size of their stocks of these animals.

Very little is known about the life-history of manatees in the Guianas. Though certainly gregarious, they are shy, elusive animals, which live totally submerged under water and only put their noses above the surface at intervals to breathe or feed. Occasionally they can be seen lying at the surface apparently basking in the sun. Despite their large size, up to lengths of 11 feet and weights of 1,000 lb., they are surreptitious in their habits and tend to disappear silently as soon as anyone approaches. They are thus very difficult animals to study in detail, particularly in a region where all water is dark in colour and thick with silt. Evidence from captivity suggests that they are long-lived. Mating probably occurs normally in shallow water. The fewness of the people who have ever seen young animals indicates that they are slow breeders, a factor which must be taken into account when assessing the future prospects of the stock.

Man is the main enemy of manatees, both because he disturbs them with his boats and kills them for his food. It seems that nowhere in the Guianas is there now any organized hunting of these animals, though in the past they suffered an active fishery. Nonetheless they are certainly killed when opportunity offers and the meat, it is said, can still be seen for sale in many places, including even the street markets in the cities of Georgetown and New Amsterdam. ${ }^{1}$ This is despite the fact that manatees are theoretically now completely protected by the wise legislation introduced in $1961 .^{2}$

Manatees are entirely herbivorous, feeding on almost any vegetation which is soft enough to be torn off by the muscular upper lips, whether the plants be floating on the surface, rooted on the bottom or growing on the banks of the rivers. Furthermore they seem to be systematic and unselective, and will eat progressively along a channel, clearing it as they go. Attention to the fact, that these feeding habits made manatees useful in weed clearance, was drawn in 1960 by Mr. W. H. L. Allsopp, Fisheries Research Officer in British Guiana, in a letter to Nature. ${ }^{3}$ He pointed out that not only were they effective in keeping free of weeds the water in ponds, such as the ornamental pools in the Botanic Gardens in Georgetown which have contained manatees since 1885, but that recent experiments showed that they could also be used to clear weed-choked trenches and channels.

1 In New Amsterdam it was said that manatee meat is now for sale about once in every two months. Formerly the carcases used to be laid out in rows along with the fish. Those would have been the days to study the reproductive anatomy, whereas nowadays information is difficult to obtain as further killing seems unsuitable.

${ }_{2}$ British Guiana. The Fisheries (Manatee Control) Regulations, 1961, made under the Fisheries Ordinance, 1956.

"Allsopp, W. H. L. "The manatee : ecology and use for weed control." Nature, vol. 188, p. $762,1960$. 
Since Mr. Allsopp started his research programme in 1959, some seventy manatees have been caught and distributed to various channels in the care of the Department of Drainage and Irrigation. According to a report from this Department in 1962, manatees were being used experimentally in seven or eight areas and in four of these they were already successfully saving money spent on weed clearing. Certainly some of the local superintendents, though sceptical at the beginning, were delighted with the manatees and no longer had to organize labour for weed clearing three or four times a year. The experiment continues, though the number of suitable waterways is limited, for manatees are easily disturbed by traffic and vulnerable to illicit attack in restricted areas.

It is difficult to give quantitative results and only three instances are available. Allsopp found that " two manatees $7 \frac{1}{2}$ feet long were capable of clearing a canal 22 feet wide and 1,600 yards long in 17 weeks ". On one of Messrs. Booker Brothers' Estates manatees were tried in 1959 and in one week seven animals cleared a trench 18 feet wide, $\frac{1}{4}$ mile long and $2 \frac{1}{2}$ to 3 feet deep which was completely choked with weed, ${ }^{1}$ including water hyacinth. Despite this creditable performance, it was considered that conditions on sugar estates made it unsuitable to use manatees because they were too easily damaged by punts transporting the cane and required too much superintendence to herd them, to keep them penned into a small area and to protect them from attack by cane-cutters. Finally, in the Georgetown waterworks, three manatees have kept quite clear since 1950 the water in two pools 15 yards wide and 150 and 250 yards long. Before the introduction the pools used to become completely covered in weed in about six weeks. Both here and in the Botanic Gardens the manatees are fed with additional grass, cut from the lawns, which is thrown into the ponds. From such results as these it is clearly impossible to produce any realistic figure for the area that could be cleared by one manatee in one year.

The most fundamental difficulty about the use of manatees for weed clearance is that it is all too expensive from the point of view of the stock. Though technique has improved, the losses in catching and transport are still high. It is more serious that so far there has been no breeding of any of the manatees used experimentally in waterways apart from occasional births in the Georgetown Botanic Gardens some decades ago. Until this grave deficiency can be overcome and manatees can be induced to breed freely in the state of semi-domestication, their large-scale use in weed clearance cannot sensibly be recommended. ${ }^{2}$ Although the stock in British Guiana may be able to survive under present pressures, it certainly could not stand the removal of large numbers of expendable individuals whether these be for local use or for transport to distant lands.

The revival of interest in manatees, stimulated by Allsopp's work,

1 The main plants cleared by manatees in British Guiana are species of Cabomba, Anacharis, Leersia, Utricularia, Nymphaea, Nelumbium and a large variety of grasses.

a It is possible that in order to be efficient weed-clearers, manatees must be hungry and that if kept hungry their fertility may be lowered. Hunger could be quantitative or qualitative. 
received world-wide publicity, for it coincided with the problem of excessive weed growth in the new Lake Kariba. There grew up much exaggerated views on the useful potentialities of manatees as weed clearers. These views were brought into perspective by the publication in 1961 by the Fisheries Division of the UN Food and Agriculture Organization, ${ }^{1}$ of a paper summarizing some of the factors which should be considered, before any serious recommendation for introduction into any new area is made, and pointing out that it was not known whether manatees were as effective in open waters as they have been found to be in confined areas. The paper ends by saying that " the introduction of manatees to other parts of the world may eventually prove to be useful, but the present state of our knowledge does not permit any recommendation to this effect". The position to-day is unchanged. However, the numbers of manatees needed to have any significant effect in large areas would seem to make the idea quite unrealistic. ${ }^{2}$

To return to the manatees of the Guianas, the main recommendations for their conservation are :-

(1) That the existing protective legislation in British Guiana should be enforced as rigidly as possible. At present its existence is all too little known, even by Government officials. There is as yet no similar legislation in Surinam.

(2) That the detailed biology, particularly of breeding, should be studied. At the same time every effort should be made to get manatees to breed in artificial waters; the provision of shallow areas for mating should be tried.

(3) That both the public and Government officers should be educated in wild life conservation by all available means, e.g. schools, press, etc.

(4) That the possibility of setting up, under international pressure, of actual and absolute wild life reserves in the Guianas, should be studied.

1 "Some notes on the use of the manatee (Trichechus) for the control of aquatic weeds." FAO Fisheries Biology Technical Paper No. 13, September, 1961.

2 This view was put forward briefly by the present writers in a letter on "Manatees of Guiana" published in Nature, vol. 196, p. 1329, 1962. 